\title{
Zonguldak’ın Meşhur Bir Unlu Mamulü: Ereğli Pidesi
}

Abdullah BADEM*

Elif KURT**

Öz

Zonguldak mutfak kültürü incelendiğinde, yörede yetişen çeşitli ot, sebze ve meyveler ile balıkçıllk faaliyetlerinin mutfak kültürünün zenginleşmesinde önemli rol oynadıkları görülmektedir. Geniş bir mutfağa sahip yörede, turistlerin ve dışarından gelenlerin deneyimlemek isteyeceği birçok yöresel lezzet yer almaktadır. Somut olmayan kültürel miras kaynaklarından biri olarak nitelendirilen yöresel lezzetler, bölgelerin kendine has karakteristik özellikleri ile şekillenmiş mutfak kültürlerinde gelişerek yöreyi temsil etmeleri, bölge kültürünün tanıtılmasında önemli rol oynamaktadır. Bu kültürel mirasların bilinirliklerinin ve alana ilişkin yapılan çalışmaların az olması, gelecek nesillere aktarılamadan yitirilmelerine neden olmaktadır. Zonguldak'ın Ereğli ilçesine özgü olan Ereğli pidesine ilişkin literatürde fazla bilgi yer almaması ve kaybolma tehlikesine sahip olmasıyla gerçekleştirilen araştırmada, Ereğli pidesinin tanıtılması ve alana kazandırılması amaçlanmıştır. Çalışma, Zonguldak'ın Merkez ve Ereğli ilçelerinde ikamet eden 11 katılımcı ile gerçekleştirilmiş ve konuya ilişkin elde edilen bulgular kayıt altına alınarak sunulmuştur. Bu çalışma sonucunda Ereğli pidesinin Zonguldak'a has bir ürün olduğu, yapımında farklı malzeme ve yöntemlerin kullanılabildiği, orijinal tariflerinde maya kullanılmadığı görülmektedir. Karadeniz Bölgesinin pideler açısından zengin olduğu, birç̧oğunun coğrafi işaretinin bulunduğu görülmüş olup, aralarındaki ayrımın net yapılabilmesi için kapsamlı bir araştırma ihtiyacı bulunduğu düşünülmektedir.

Anahtar Kelimeler: Ereğli pidesi, Zonguldak mutfağı, Zonguldak kültürü, Yöresel yemekler

\section{A Famous Bakery Product of Zonguldak: Ereğli (Pita) Pidesi}

\begin{abstract}
When the culinary culture of Zonguldak is examined, it is seen that various herbs, vegetables and fruits grown in the region and fishing activities play an important role in the enrichment of the culinary culture. The region, which has a wide cuisine, has many local flavors that tourists and outsiders would like to experience. Local flavors, which are described as one of the intangible cultural heritage resources, develop in the culinary cultures shaped by the unique characteristics of the regions and represent the region, playing an important role in the promotion of the regional culture. The lack of awareness of these cultural heritages and the lack of studies on the area cause them to be lost before they can be passed on to future generations. Ereğli pide, which is unique to Zonguldak's Ereğli district, has a little information in the literature and it has the risk of being lost, in the preliminary research, it was aimed to introduce Ereğli pita and bring it to the literature. The study was carried out with 11 participants residing in the Merkez and Ereğli districts of Zonguldak, and the findings related to the subject were recorded and presented. As a result of this study, it is seen that Ereğli pita is a product unique to Zonguldak, different materials and methods can be used in its production, and yeast is not used in its original recipes. It has been seen that the Black Sea Region is rich in pides, most of them have geographical indications, and it is thought that a comprehensive research is needed to make a clear distinction between them.
\end{abstract}

Keywords: Ereğli (pita) pidesi, Zonguldak cuisine, Zonguldak culture, Local dishes

Geliş/Received: 31.08 .2021

Kabul/Accepted: 30.12 .2021

- Bu çalışmada kullanılan verilerin toplanması için gerekli olan etik kurul izin belgesi Karamanoğlu Mehmetbey Üniversitesi Etik Kurulu'ndan 26.04.2021 tarih ve 36 sayılı karar/sayı ile alınmıştır.

\footnotetext{
* Dr. Öğr. Üyesi, Karamanoğlu Mehmetbey Üniversitesi, SBMYO, Otel Lokanta ve İkram Hizmetleri Bölümü, abadem@kmu.edu.tr, Orcid: 0000-0001-8518-6366

** Yüksek Lisans Öğrencisi, Karamanoğlu Mehmetbey Üniversitesi, Sosyal Bilimler Enstitüsü, Gastronomi ve Mutfak Sanatlar1, krt.elif@hotmail.com, Orcid: 0000-0003-1342-4630

(Makale türü: Araştırma Makalesi)
} 


\section{Giriş}

Yaşam için gerekli enerji, yiyecek içeceklerin temin edilmesi ve tüketime hazır hale getirilmesi ile karşılanmaktadır (Beşirli, 2010: 159). İnsanların ilkçağdan beri yaşamını sürdürebilmek ve çevresindekileri yaşatabilmek için besin arayışında olması, yeme içmeyle ilgili bazı kuralları ortaya çıkartmıştır (Güvenç, 1999: 204; Halıc1, 1999). Bu kurallar zamanla, toplumlara has benlik, yargı, dini inanç ve geleneksel törenleri etkileyerek kendilerine özgü beslenme ve mutfak kültürünün meydana gelmesini sağlamıştır (Halıc1, 1999, Işık vd. 2017: 87). Her milletin, ülkenin ve toplumun, tarihsel geçmişine, beslenme alışkanlıklarına, damak zevkine, tarım üretimine, sosyo ekonomik düzeyine (Sürücüoğlu ve Özçelik, 2007), diğer toplumlar ile etkileşimine (Aksoy ve Üner, 2016), gelenek göreneklerine (Çelik, 2010) ve dini inanışlarına (Şengül ve Türkay, 2015: 600) göre şekillenmiş bir mutfağı vardır. Karadeniz bölgesi, yağışlı iklimi, zengin bitki örtüsü ve yeşil doğası ile diğer bölgelerden ayrılarak batı, doğu ve iç kısımlarındaki beslenme alışkanlıkları, toprak özellikleri ve pişirme yöntemleri ile kendi içerisinde de farklılaşan bir mutfak kültürüne sahiptir (Cömert ve Özata, 2016: 1964-1965; Sabbağ ve Boğan, 2019: 58).

Bu çalışma ile Batı Karadeniz Bölgesi’nde yer alan Zonguldak ilinin mutfak kültürü ve yöreye özgü bir lezzet olan Ereğli pidesinin tarihi ve yapılışı hakkında bilgi edinebilmek için nitel araştırma yöntemlerinden olan mülakat tekniği ile araştırma yapılmış ve elde edilen veriler işlenerek literatüre kazandırılması amaçlanmıştır.

\section{Zonguldak ve Mutfak Kültürü}

Bat1 Karadeniz'in maden ve sanayi şehri olarak bilinen Zonguldak, 1 Nisan 1924 tarihinde kurulmuştur (Batı Karadeniz Kalkınma Ajans1, 2016: 8-24). Hititler, Frigler, Lidyalılar, Persler, Makedonya krallığı ile Roma ve Bizans imparatorlukları Zonguldak ve çevresinde hâkimiyet kursalar da Anadolu Selçuklu devleti ile başlayarak Türkiye Cumhuriyetine kadar devam eden süreçte Türkİslam şehri olmuştur (Işkın ve Sarışsı, 2019: 533). Merkez İlçe, Alaplı, Çaycuma, Devrek, Gökçebey, Kdz. Ereğli, Kozlu, Kilimli ilçelerinden oluşarak engebeli bir arazi yapısına sahip olan şehirde 17 belde ve 372 köy vardır (BAKKA, 2016: 8).

Zonguldak'ın köklü tarihi, sosyo-ekonomik durumu, 1lıman iklim özelliği, coğrafi konumu, tarım ürünleri, maden ocaklarının çokluğu ile Bartın ve Amasra'ya geçen deniz yolu üzerindeki kıyılara sahip olması yöre mutfağının şekillenmesine yardımcı olan temel olgulardır (Işskın ve Sarıı̧ık, 2019: 533; Akbıyık, 2021). Yörenin engebeli bir yapıya sahip olması ile ekili-dikili tarım alanlarının parçalı ve dar olması gibi coğrafi özelliklerine rağmen yetiştirilen ürün çeşidi fazladır (Işkın ve Sarışık, 2019). Yetiştirilen ürünler arasında kuzu kestanesi, Osmanlı çileği, dağ çileği, kızılcık (kiren), kuşburnu, bögürtlen, fesleğen, nane, kestane, ahlat, zılbıt (1spit) otu, buğday, mısır, bakla, fasulye, karayemiş (taflan), döngel (muşmula, beşbıyık), bal kabağı, ısırgan, fındık, ceviz, ebegümeci, barbunya, bakla ve karalahana (mancar) Zonguldak mutfağının başlıca yiyecekleri arasında yer almakta ve farklı şekillerde 
kullanılmaktadır (Nöraşin, 2014, Işkın ve Sarıışı, 2019: 533). Yöre halkının mutfakta kullandıkları kazan, sini, büyük tencere, tepsi, bakır sahan, tava, güğüm, çömlek, bakraç, kepçe, sefer tası ve kase gibi çeşitli geleneksel ekipmanların bol miktarda olması ile zengin bir mutfak kültürüne sahip olduğu anlaşılmaktadır (Işkın ve Sarışık, 2019: 533). Yöre mutfağında sebze, tahıl ve kuru baklagil çeşitleri ile hazırlanan zengin çorbalar, balık türleri, küçükbaş ve kümes hayvanlarına ait etler ve unlu mamullerden hazırlanan yemek türleri yer almaktadır (Nöraşin, 2014).

Turistlere, kültürel mirası yerinde ziyaret etme, ev sahibi toplulukların kültürel geçmişini aktarma ve deneyimleme imkanı sunan yöresel mutfaklar, yöredeki iklim ve coğrafi şartlar ile bölgeye özgü özelliklerin yöre halkı tarafindan harmanlanmasıyla oluşmaktadır (Şengül ve Türkay, 2016: 91). $\mathrm{Bu}$ mutfaklarda üretilen gıdalara, kültür, tarih ve yaşam tarzının yansıtılıp, geleneksel yöntem ve hammaddelerinin kullanılması ile yöresel ürün özelliği kazandırılmaktadır (Berard ve Marchenay, 2008: 5). Her kentin kendine has yöresel ürünleri vardır. Zonguldak'ın da mutfak kültürü ile özdeşerek ünlenen başlıca yöresel ürünlerini Ereğli Pidesi, Ereğli keşi, kömeç, Devrek simidi, mantarlı börek (kanlıca ve sarıkız mantarı), manda yoğurdu, malay, beyaz baklava, göce çorbası, baklalı mancar, kiren çorbası, kabak gözlemesi, beddam yemeği, çöpele, gartlaç, zılbıt kavurması, ıslama ve kaygana oluşturmaktadır (Nöraşin, 2014).

\section{Türklerde Ekmek}

Orta Asya'dan Anadolu'ya gelen Türkler, göç esnasında birçok milletle kültür alışverişinde bulunmuştur. Yiyecek olarak kullanılan gıdalardan pişirme yöntemlerine kadar mutfakla ilgili birçok şeyde etkileşilen alanlar arasındadır. Anadolu'ya yerleşince tarımla uğraşmaya başlamış, buğday, arpa, çavdar ve darı yetiştirmeye başlamıştır. Elde edilen tahıllar öğütülerek değişik ekmeklerin yapımında kullanılmıştır. Zamanla değişik pişirme şekilleri uygulanmış, sac, fırın, tandır, köz, kül gibi araç ve yöntemlerle ekmekler pişirilmiştir (Çetinkaya, Şimşek ve Yıldız, 2019: 93). Tarihçesi on iki bin yıl öncesine uzanan ekmeğin (Emeksizoğlu, 2017: 24), Türk mutfak kültüründe önemli bir yeri vardır (Arıkan, 2019: 54). Anadolu'da daha önce yaşayan uygarlıkların da (Hititler vd.) pide ve bazlama gibi ince ve yuvarlak ekmek yaptıkları, yine bu coğrafyaya yakın yerler olan Antik Yunan ve İran devletlerinde de benzeri ekmeklerin yapıldığı bilinmektedir (Işın, 2021: 55,81,123). Türklerin Anadolu'ya göçü sonrası ekmek yapımının daha da yayıldığı ifade edilmektedir. Anadolu'da Selçuklu mutfağından günümüze ak ekmek, has ekmek (buğday ekmeği), arpa ekmeği, çavdar ekmeği, mısır ekmeği, darı ekmeği gibi ekmekler gelmiştir. Bu ekmekler için Türklerin "yufka, bazlama, büskeç, sinçü, çukmin ya da pide” ismini (Alyakut ve Küçükkömürler, 2018; Kuter, 2013; Şahin, 2016), bazı uygarlıkların ise "ötmek, "etmek" ve "nan" kelimesini kullandığı belirtilmiştir (Alyakut ve Küçükkömürler, 2018). Ekmeklerin yapımları zamanla değişmiş ve geliştirilmiş, böylece yufka, tandır, pide, bazlama ve fodula gibi ekmekler daha yaygın yapılır hale gelmiştir (Badem, 2021: 265; Çetinkaya 2020: 135). 
Karadeniz Bölgesi'nde mısır, buğday, yulaf ve çavdardan ekmek yapılmaktadır. Doğu Karadeniz'de aşırı yağmur almasından dolayı buğday tarımından ziyade mısır tarımı yapılmaktadır. Bu bölgede mısır ekmeği (mçkudi) yaygın yapılırken bölge genelinde yukarıda bahsi geçen diğer ekmek türlerine de rastlanmaktadır (Civelek, 2006: 77,170).

Türk beslenme alışkanlıklarında ayrı bir öneme sahip olan hamur işleri, zamana karşı formunu en iyi koruyabilen gıdaların başında gelmektedir. 15. yüzyıldan beri varlığı koruyan pideler (Yerasimos 2019: 145,148), Selçuklu ve Osmanlı döneminde yaygın olarak tüketilen ekmek çeşitlerinden biridir (Sabbağ ve Boğan 2019: 19). Pide" sözcüğü Yunanca "peptos" (pişmiş) kelimesine dayanmaktadır, “yumuşak ve ince ekmek" anlamına gelmektedir. "pitta, pita, pitah” sözcükleri peptos kelimesine dayanmakta olup Türkçeye "pide”, İtalyancaya "pizza”, Bulgarcaya "pita” olarak dönüşüp geçmiştir (Tez, 2021: 60). Pide, pizzanın atası olarak ifade edilmektedir (Işın, 2021:229). Başlangıçta sadece un, su ve tuz ile hazırlanan hamur parçalarının sonraları çeşitli harçlarla doldurulmaya başlandığı (Yerasimos 2019: 140) ve yassı biçimine getirilip pişirilerek pide elde edildiği belirtilmektedir (Sabbağ ve Boğan 2019: 19). Kaynakların sınırlı olması nedeniyle mayalı ya da mayasız hazırlanan bu ekmeklerin içerisine nelerin katıldığ 1 sadece tahmin edilebilmektedir. Muhtemelen başlangıçta sadece ekmek için pide kelimesi kullanılmıştır.

Türkiye'nin birçok yerinde değişik pideler yapılmaktadır. Nitekim birçoğu için coğrafi işaretleme yapılmıştır. Coğrafi işaretlemesi yapılan bazı pideler; Aksaray Şerbetli Pidesi, Akçakoca Mancarlı Pidesi, Antep Tırnaklı Pidesi / Gaziantep Tırnaklı Pidesi / Antep Pidesi, Bafra Pidesi, Derepazarı Pidesi, Emirdağ Yumurtalı Pidesi, Kadınhanı Tahinli Pidesi, Karacasu Pidesi, Nazilli Pidesi, Sürmene Pidesi, Terme Pidesi, Ulaş Etli Pidesi ve Çarşamba Pidesi iken, işaretleme süreci devam eden pideler; Bursa Pideli Köfte, Bursa Tahinli Pide, Kırkağaç Çakal Pideli Paça, Çakal Pidesi ve Şereflikoçhisar Tahinli Pidesi sayılabilir. Nitekim adı pide olmamakla birlikte pide statüsünde sayılabilecek Konya Etliekmek, Daday Etli Ekmeği, Gaziantep Lahmacunu, Gaziantep Nar Ekşili Soğanlı Lahmacun, Tarsus Fındık Lahmacunu ve Urfa Lahmacunu (Kıymalı Ekmeği) gibi yiyecekler de bulunmaktadır. Pidelerin geneli yağlı ve et vb. iç ile hazırlanırken, Aksaray Şerbetli Pidesi ve Kadınhanı Tahinli Pidesi gibi yiyecekler ise tatı olarak yenilmektedir. Antep tırnaklı pidesi gibi ekmek türü pideler halen yaygın yapılan pideler arasındadır. Türk kültüründe özellikle Ramazan ayında, oruç boyunca, bayrama kadar firınlarda pide yapılması da özgün bir gelenek olarak devam etmektedir. Yapımında kullanılan malzeme, görünüm ve yapım süreci gibi kriterlere göre Ereğli pidesine benzerlik gösteren pideler; Bafra pidesi, Çarşamba pidesi, Derepazarı pidesi, Emirdağ yumurtalı pidesi, Konya Etliekmek, Karacasu pidesi, Nazilli pidesi, Sürmene pidesi, Terme pidesi ve Ulaş Etli Pidesi sayılabilir. Bazı pidelere ait resimler Şekil 1'de verilmiştir. 


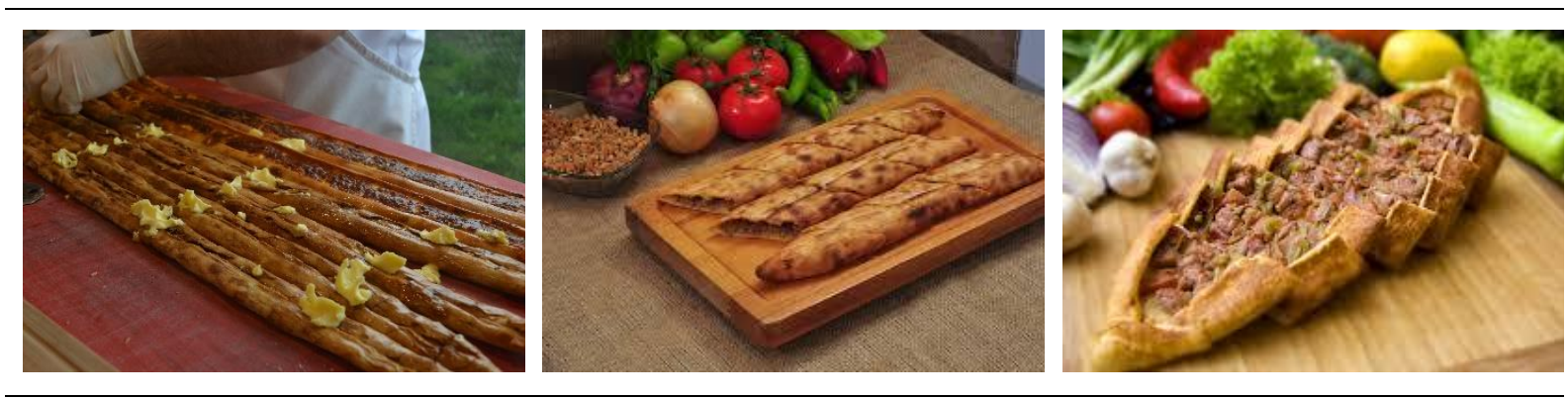

Bafra pidesi / Samsun

Çarşamba pidesi / Samsun

Terme pidesi / Samsun
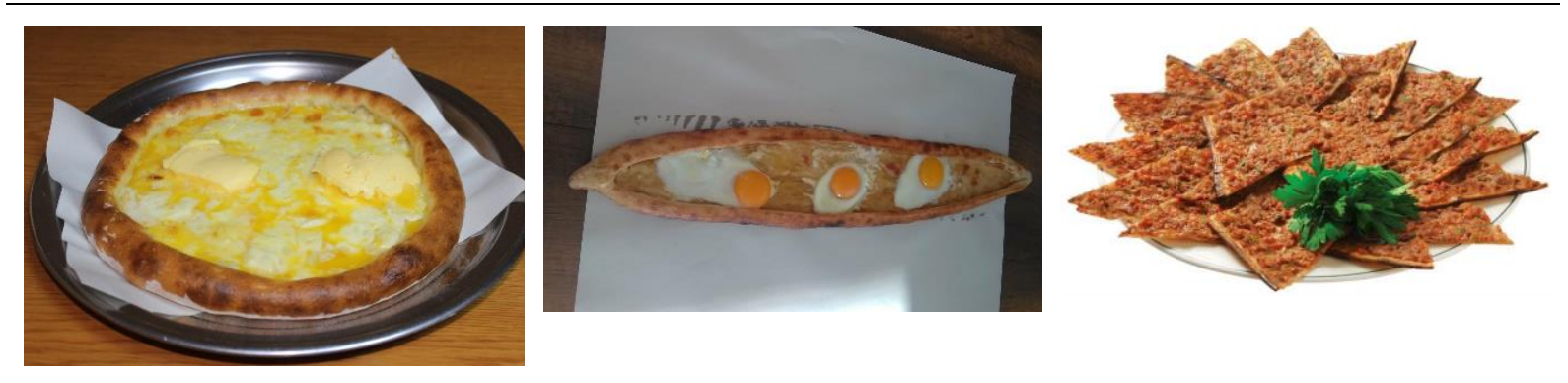

Derepazarı pidesi / Rize

Emirdağ yumurtalı pidesi /Afyon

Konya Etliekmek
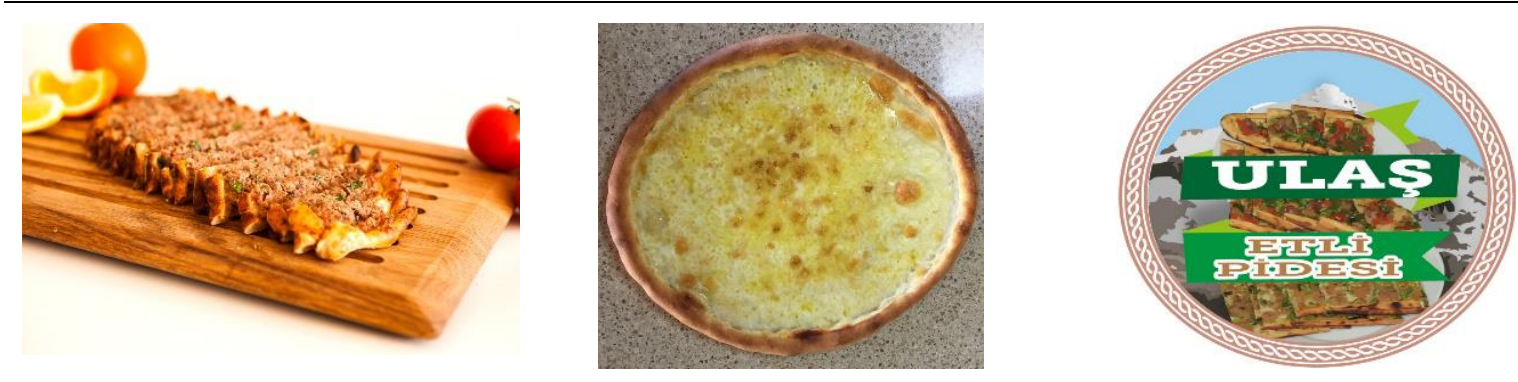

Nazilli pidesi / Aydın

Sürmene pidesi

Ulaş Etli Pidesi / Sivas

Şekil 1. Bazı Pidelerin Görselleri (Fotoğraf: https://ci.turkpatent.gov.tr/anasayfa).

\section{Yöntem}

Nitel araştırma yöntemi, tümevarım yöntemi ile sözel bilgi parçacıklarının elde edilmesi, bir bilgi havuzu oluşturulması ve işlenmesidir (Kozak, 2018: 78,79). Nitel araştırma yöntemlerinde olan görüşmelerde (Kozak, 2018: 81) örneklem büyüklüğünün 5-25 kişi arasında olması yeterli görülmektedir (Saunders, Lewis, and Adrian, 2012). Araştırmaya gönüllü katılan, Zonguldak'ın Merkez ve Ereğli ilçelerinde ikamet eden, araştırma konusuna hakim olduğu düşünülen kişile, amaçlı örnekleme yöntemi ile seçilerek Temmuz 2021 tarihinde görüşme sağlanmıştır. Katılım sağlayan bireyleri 27-72 yaş aralığındaki 11 erkek aşçı oluşturmaktadır. Yapılan görüşmeler, araştırmaya katılan tüm bireylerden izin alınıp ses kayıt cihazı ile kayıt altına alınarak gerçekleştirilmiştir. Görüşmeler, 45-60 dakika arasında yüzyüze gerçekleştirilmiştir. Çalışmada cevaplanması için hazırlanan sorular, daha önce yapılmış benzer bir çalışmaya başvurularak oluşturulmuştur (Badem ve Akturfan, 2020: 48). Makale, Türk mutfağında geniş bir yeri olan Ereğli pidesinin özelliği, Zonguldak'ta ne zamandan beri yapıldığı, geçmişten günümüze hazırlanma süreci, içerisinde kullanılan malzemeleri, pişirme aşamaları ve 
yöntemi ile servis edilme şekli hakkında veri toplanmıştır. Veri toplama yöntemlerinden biri olan görüşme ile yarı yapılandırılmış soruların sorulması ve elde edilen verilerin düzenlenmesi ve içerik analizi ile tamamlanmıştır. Veri işlemede betimsel analiz yöntemi tercih edilmiştir. Bu çalışmada kullanılan verilerin toplanması için gerekli olan etik kurul izin belgesi Karamanoğlu Mehmetbey Üniversitesi Etik Kurulu'ndan 26.04.2021 tarih ve 36 sayılı karar/sayı ile alınmıştır.

\section{Bulgular}

Araştırmaya katılan 11 kişiye ait demografik bilgiler Tablo 1'de verilmiştir.

Tablo 1: Katılımcıların demografik özellikleri

\begin{tabular}{llllll}
\hline Kk & Adı Soyadı & Doğum yılı & Memleketi & Cinsiyet & Mesleği \\
\hline 1 & S.A. & 1986 & Zonguldak & Erkek & Aşçı \\
\hline 2 & F.K. & 1980 & Zonguldak & Erkek & Firın Ustası \\
\hline 3 & B.Ç. & 1994 & Zonguldak & Erkek & Aşçı \\
\hline 4 & Y.Ç. & 1959 & Zonguldak & Erkek & Aşçı \\
\hline 5 & E.M. & 1981 & Zonguldak & Erkek & Aşçı \\
\hline 6 & E.Ç. & 1985 & Zonguldak & Erkek & Aşçı \\
\hline 7 & S.Ö. & 1973 & Zonguldak & Erkek & Aşçı \\
\hline 8 & Ü.Ç. & 1987 & Zonguldak & Erkek & Aşçı \\
\hline 9 & M.T. & 1964 & Zonguldak & Erkek & Pideci \\
\hline 10 & I.T. & 1974 & Zonguldak & Erkek & Frrın Ustası \\
\hline 11 & N.T. & 1963 & Zonguldak & Erkek & Aşçı \\
\hline
\end{tabular}

Araştırma sonucu elde edilen bulgulara göre, "Kaç yıldır Ereğli pidesi yapıyorsunuz? sorusuna bazıları "20-25 y1ldır" (KK1, 4, 10, 11), bazıs1 "26 yıldır” (KK2), bazıs1 “4 yıldır” (KK3), bazılar1 "15 yıldır” (KK5, 6), bazıları "30 yıldır” (KK7, 9), bazıs1 "10 yıldır” (KK8) Ereğli pidesini yapıyorum cevabını vermiştir.

"Ne kadar sıklıkla Ereğli pidesini yapıyorsunuz?" sorusuna bazı katılımcılar "sık s1k” (KK1, 2, $4,5,7,8)$, cevabını verirken bazıları "Genelde sık sık ama müşteri talebine bağlı olarak değişebiliyor." (KK3, 6, 9-11) cevabını vermiştir.

"Ereğli pidesini hangi dönemde yaparsınız? Bu dönemin bir özelliği var mıdır?” sorusuna bazıları "Herhangi bir dönemi yok, müşteri talebine bağlı olarak yapıyorum." (KK1-10), bazısı "Sipariş üzerine dügünler için hazırlanabiliyor. Ancak biraz pahalıya kaçtığı için herkesin tercihi arasında yer almıyor.” (KK4), bazıları "Düğün, cenaze ve bayramlarda yapılıyor. Ancak mevlütlerde daha çok tercih ediliyor" (KK7, 11) cevabını vermiştir. 
“Ereğli pidesinin yapılışını kimden/nerden öğrendiniz?” sorusuna bazıları “ustalarım” (KK1-3, 5-11), bazıs1 "abim” (KK2), bazısı “dedem” (KK3), bazıs1 "Ereğli pidesini küçük yaşlardan beri yedikçe kendi tarifimi oluşturdum. İçerisinde var olan malzemeler belli sonuçta, ben de ona göre bir tarif oluşturdum.” (KK4) cevabını vermiştir.

“Ereğli pidesi yapımında kullanılan araç gereçler nelerdir?” sorusuna katılımcıların tamamı "bıçak, pide küreği, hamur yoğurma makinesi, hamur açma makinesi”, bazıları "tahta kaşık" (KK3-6, 8-10), bazıları "kevgir" (KK1, 2, 7, 11), bazıları "çelik tencere" (KK3-7, 10, 11), bazıları "alüminyum tencere" (KK1, 2, 8, 9), bazıları "merdane" (KK1, 3, 6, 7, 9), bazıları "hamur kasaları" (KK2, 7, 9, 10), bazıları "tepsi” (KK1-6, 8, 11), bazısı "zırh bıçağı” (KK6), bazıs1 “ölçü kapları” (KK6), bazısı "mutfak robotu” (KK8), bazıları "gastronom” (KK2, 8, 10) kullandıklarını belirtmiştir.

“Ereğli pidesi yaparken hangi malzemeleri kullanırsınız?” sorusuna katılımcıların tamamı "dana kıyma, soğan, tuz, karabiber, un, su, yaş maya, şeker”, bazıs1 "kimyon” (KK3), bazısı "pul biber” (KK2), bazıları "maydanoz" (KK1-4, 6, 7, 11), bazıları "tereyağı" (KK1-10), bazıları "ayçiçek yağı”" (KK4, 10, 11), bazısı "zeytinyağı" (KK1), bazısı "yumurta sarısı" (KK3) cevabını vermiştir. Ayrıca katılımcıların tamamı Ereğli pidesinin iç harcına maydanoz eklendiğini ama maydanozu sevmeyen müşterilerin çokluğu nedeniyle maydanozu çok sık kullanmadıklarını belirtmişlerdir. Katılımcılardan bazıları da "Ereğli pidesinin hamuruna aslında maya eklenmiyor ama hamur, maya ile daha çabuk kıvama geldiği için çok az da olsa kullanmak zorunda kalıyoruz.” (KK1, 7, 11) bilgisini vermişlerdir.

“Malzemelerin ölçüsü hakkında bilgi verir misiniz?” sorusuna bazısı "İç harc1; 1 kg dana kıyma (dana kaburga etinden çekilmiş), $800 \mathrm{~g}$ soğan, 1/2 bağ maydanoz, $200 \mathrm{~g}$ karabiber, $100 \mathrm{~g}$ tuz, 1 çay bardağı zeytinyağı. Hamur; $5 \mathrm{~kg}$ un, 3 litre su, 1 avuç tuz, $100 \mathrm{~g}$ yaş maya. Piştikten sonra pidenin içerisine eklemek için de 50 g tereyağı." (KK1), bazısı "İç harcı; 3 kg orta yağlı dana kıyma, 2 kg soğan, $250 \mathrm{~g}$ tereyağı, $1 / 2$ bağ maydanoz, göz kararı tuz, karabiber ve pulbiber. Hamurunu göz kararına göre yaptığım için net bir tarif veremem ama malzeme olarak un, su, tuz, şeker ve çok az bir yaş maya kullanıyorum." (KK2), bazısı "İç harc1; 1 kg dana kıyma, 2 adet orta boy soğan, 50 g tereyağı, 1 bağ maydanoz, birer tutam tuz, karabiber ve kimyon. Hamur; $1 \mathrm{~kg}$ un, 100-150 ml su, 1 tutam tuz, şeker ve yaş maya. Pidenin üzerine sürmek için 1 adet yumurta sarısı ve pide piştikten sonra içerisine eklemek için 50 g tereyağı.” (KK3), bazısı “ (1 porsiyon Ereğli pidesi için) İç harc1; 100 g orta yağlı dana kıyma, 40 g soğan, 1 çorba kaşığı ayçiçek yağı, birer tutam tuz, karabiber ve ince doğranmış maydanoz. Hamur; $100 \mathrm{~g}$ un, $1 / 2$ bardak su, 1 çay kaşığından daha az yaş maya, göz kararı tuz ve şeker. Pide piştikten sonra içerisine eklemek için 40 g tereyağı." (KK4), bazısı "1 porsiyonluk iç harç için 120-130 g dana kıyma, 30-40 g soğan, 1 çorba kaşığı tereyağı, göz kararı tuz ve karabiber. Hamur; 4-5 litre su, 5-6 kg un, 1 su bardağ 1 şeker, 1 su bardağ 1 tuz, 2 kibrit kutusu kadar yaş maya. Pide piştikten sonra içerisine eklemek için 1 çorba kaşığı kadar tereyağı." (KK5), bazısı "1 porsiyonluk iç harç için 200 g yağsız dana kıyma, 20 g soğan, 50 g tereyağı, göz kararı tuz ve karabiber, müşteri isteğine göre de maydanoz. Hamur; $5 \mathrm{~kg}$ un, göz kararı su, 2 yemek kaşığı yaş maya, 1 yemek kaşığı tuz, 1 yemek kaşığı şeker.” (KK6), bazısı 
"İç harç; $1 \mathrm{~kg}$ dana kıyma (dana döşten tek çekilmiş), $1 \mathrm{~kg}$ soğan, 250 g tereyağı, göz kararı tuz ve karabiber, isteğe bağlı maydanoz. Hamuru için kesin bir ölçü veremem, genelde göz kararı oluyor ama malzeme olarak un, tuz, su, şeker ve çok az yaş maya kullanıyorum." (KK7), bazısı "İç harç; 4 kg dana kıyma, 1.5 kg soğan, 500 g tereyağı, 1 yemek kaşı̆̆ tuz, 1 tatlı kaşığı karabiber. Hamur; 15 kg un, 10 litre su, 15-20 g kadar yaş maya, $150 \mathrm{~g}$ tuz, $150 \mathrm{~g}$ şeker." (KK8), bazısı "İç harç; $1 \mathrm{~kg}$ dana kıyma, 2 tane soğan, göz kararı tuz ve karabiber. Hamur; 1 kg un, 4 bardak su 1 çorba kaşığ tuz, $1 / 2$ çorba kaşığ 1 şeker, 25 g yaş maya. Pide piştikten sonra içerisine eklemek için de 1 çorba kaşığı tereyağı.” (KK9), bazısı "Hamur için 25 kilogramlık bir un tercih ediyorum. Diğer malzemeleri de göz kararı eklediğim için net bir ölçü veremem. Zaten genel malzemelerini un, su, tuz, yaş maya ve şeker oluşturuyor. İç harç; 1 kg dana kıyma (dana kaburga etinden çekilmiş), 400-500 g soğan, 2 yemek kaşığı kadar ayçiçek yağı, göz kararı karabiber ve tuz. Pide piştikten sonra içerisine eklemek için 60 g tereyağı, müşteri içerisinde yumurta isterse de 1 adet yumurta." (KK10), bazısı "İç harç; 1 kg dana kıyma, 1 kg soğan, çok az ayçiçek yağı (malzemelerin tencereye yapışmaması için), 1/4 bağ maydanoz, göz kararı tuz ve karabiber. Hamurunun malzemelerinde un, su, tuz, yaş maya ve şeker var ama kesin bir ölçüsünü veremem. Çünkü ben göz kararı olarak ayarlıyorum. Hafif nemli ve ele yapışmayan bir hamur olması gerekiyor, onu da ben ayarlıyorum zaten.” (KK11) cevabını vermiştir.

“Ereğli pidesi yapmak için kullanılan malzemelerin kendine özgü özellikleri var mı?” sorusuna bazısı "komili zeytinyağı" (KK1), bazısı "yağsız kıyma" (KK2), bazıları "Vakfikebir tereyağı”" (KK1, 2-6, 8-10), bazıları "doğal ortamda beslenmiş bir besi hayvanının kıyması" (KK4), bazıları "1. sınıf un" (KK7), bazıları "dana kaburga etinden çekilmiş kıyma” (KK10) cevabını vermiştir.

"Ereğli pidesinin yapım aşamalarını anlatır mısınız?" sorusuna bazısı "Önce iç harcı yapılır ve soğumaya bırakılır. İç harcı için de tencereye kıyma eklenir ve 20 dakika kavrulur. Daha sonra zeytinyağı ile ince doğranmış soğan ve maydanoz eklenir. Hepsi birlikte 15 dakika daha kavrulur. İşlem bitince ocak kapatılıp tuz ve karabiber eklenir. Harç son kez karıştırılır ve tencerenin kapağ kapatılarak hem dinlendirmeye hem de soğumaya bırakılır. Hamur için tüm malzemeler hamur yoğurma makinesine eklenir ve tüm malzemelerin birbirleriyle harmanlanması beklenir. İstenilen kıvama gelen hamur 1 saat dinlendirilir ve dinlenen hamur belirli gramajlarda kesilip beze haline getirilir. Az bir un ve merdane yardımıyla bezeler açıldıktan sonra hamurun içerisine yeterli miktarda iç harç eklenir ve pidenin üzeri kapatılır. Hazır olan pide $240^{\circ} \mathrm{C}^{\prime}$ deki elektrikli firında $12-13$ dakika pişirilir. Pişen pidenin kapalı yeri açılır ve tereyağı parçaları eklenerek servis edilir." (KK1), bazısı "Kıyma tencereye eklenir ve 10-15 dakika kadar orta ateşteki ocakta karıştırılarak kavrulur. Kıyma çok yağlıysa ve bu işlem sonunda çok fazla yağ bıraktıysa bu yağ alınır. Alınan yağın ardından tereyağı eklenip karıştııılır. Bu karışıma ince doğranmış soğanlar da eklenip karıştırma işlemine devam edilir. 10 dakika daha kavrulan harcın içerisine baharatlar eklenip son kez karıştırılır ve ocak kapatılır. Harç büyük bir tepsiye dökülür ve içerisine ince doğranmış maydanoz eklenip harmanlanır ve soğumaya bırakılır. Hamur yoğurma 
makinesine tüm malzemeler eklenip makine çalıştırılır. Ele yapışmayan yumuşak bir hamur olacağa kadar yoğrulması beklenir. Çok sertse az su dökülür ya da çok yapışkan bir hal aldıysa un eklenerek hamurun toparlanması sağlanır. Ben hamuru dinlendirmeden önce farklı bir işlem uyguluyorum. Yoğurma işlemi bittikten sonra hamurun üzerine bir miktar un döküyorum (hamurun üzerini kaplayacak kadar) ve makineyi bir-iki kez daha karıştırması için açtıktan sonra hamuru dinlenmesi için kenara alıyorum (10 dakika). Hamur içerisinde un parçaları kaldığında daha iyi kıvama geliyor ve daha lezzetli oluyor. Dinlenen hamuru kesilip beze yapıldıktan sonra hamur kasalarına alınır ve 1 saat kadar mayalanması için tekrar dinlendirilir. Dinlenen hamur, bir miktar un ve kepekle (daha iyi kızarması için) birlikte hamur açma makinesinde açılır. Açılan hamurun içerisine iç harçtan ilave edilip kapatılır. Hazır olan pideler $280-300^{\circ} \mathrm{C}$ 'deki taş firında 10 dakika kadar pişirilir. Pide fırından çıktıktan sonra yanından kesilerek içerisine tereyağı eklenir ve üzerine de tereyağı sürülüp dilimlenerek servis edilir.” (KK2), bazısı "Kıyma ve ince doğranmış soğan tencereye birlikte konularak 10-15 dakika kadar kavrulur. Kavurma işlemi bitince ocak kapatılıp baharatlar ve ince doğranmış maydanoz eklenip karıştırılır. Bütün hamur malzemeleri hamur yoğurma makinesine eklenerek birbirleriyle özleşene kadar yoğrulmaya bırakılır. Özleşen hamur, 10 dakikalık bir mayalama süreci için dinlendirilir. Daha sonra hamur kesilip bezelere ayrılır ve tekrardan 15-20 dakikalık bir mayalama işlemi için dinlendirilir. Bir miktar unla birlikte bezeler hamur açma makinesinde açılır ve merdaneyle birlikte hamur biraz daha inceltilir. Uzun ve hafif yassı şeklinde açılan hamurun içerisine harçtan konulur ve pidenin üzeri kapatılır. Üzerine 1 adet çırpılmış yumurta sarısı sürülüp $180^{\circ} \mathrm{C}$ 'deki taş fırında pişirilir. 5 dakika sonra pide çıkartılıp ters çevrilir ve çevrilen kısmına tekrar yumurta sarısı sürülerek firına gönderilir. 10-15 dakikaya hazır olan pide firından çıkartılır ve yan tarafından uzunlamasına bıçakla kesilir. Kesilmiş yerden pidenin içerisine tereyağı eklenir ve dilimlenerek servis edilir." (KK3), bazısı "Kıyma, ince doğranmış soğan ve ayçiçek yağ1 tencereye konularak birlikte kavrulur. Kavurma işlemi tamamlanınca ocak kapatılır ve tuz, karabiber, maydanoz eklenip harmanlanır. Hamur için gerekli tüm malzemeler bir tekneye eklenir ve yoğrulur. Yoğrulan hamur 30 dakika firının yanında dinlendirilir. Dinlenen hamur 150-200 gram gelecek şekilde kesilip beze yapılır ve 10 dakika dinlendirilir. Dinlenen bezeler makine yardımıyla açılır. El yardımı ile hamur biraz daha uzun ve ince olacak şekilde açılıp içerisine soğumuş harç eklenir. İşlem bitince açılmış hamurun yanlarından tutulup üzerinde birleştirilerek kapatılır ve $280^{\circ} \mathrm{C}$ 'deki taş firında 7-8 dakika pişirilir. Pişen pideyi fırından çıkartılır ve francala ekmeği tarzında yanından keserek içerisine tereyağı (40 gram kadar) eklenip dilimlenir. Bol tereyağlı istenirse gramaj 50-60 olarak da ayarlanabilir ya da yağ istenmezse hiç yağ eklemeden servis yapılır." (KK4), bazısı "Harcın soğuması için ilk önce iç harç yapılır. Kıyma, yağsız tencereye eklenir ve suyunu salana dek karıştırılır. Suyunu saldığında içerisine ince doğranmış soğanlar eklenir. İkisi birlikte kısık ateşte 15 dakika kavrulur. Ocağı kapatmaya yakın tuz, karabiber ve 1 yemek kaşığı kadar tereyağı eklenip karıştırılır. Hazır olan harç soğumaya bırakılır. Hamur için gerekli tüm malzemeler hamur yoğurma makinesine eklenir ve birbirleriyle harmanlana kadar karışması beklenir. Hazır olan hamur, makinenin kazanında 2 saat mayalandırılır. 2 saat sonunda hamurlar 200-220 gram olacak şekilde kesilip beze yapılır. Bu bezeler de 
tepside 20 dakika bekledikten sonra bezeler bir miktar unla birlikte makinede açılır. Soğumuş harç, ince ve uzunlamasına açılmış hamurun içerisine eklenir ve üzerinden kapatılır. $200-250^{\circ} \mathrm{C}$ 'deki firında 10 12 dakika pişirdikten sonra üzerine bir çorba kaşığı kadar tereyağı sürülür ve dilimlenerek servis edilir. İsteğe bağlı olarak pide üzerinden açılıp içine de tereyağı eklenebilir." (KK5), bazısı "Hamur için gerekli tüm malzemeler hamur yoğurma makinesine eklenip makine çalıştırılır. Malzemeler zaten 10 dakikada toparlanarak hamur haline geliyor ve bu süreçte kendi içerisinde bir mayalama süreci olduğu için hamurun 10 dakika kadar dinlenmesi yeterli oluyor. 10 dakika sonra hamur tezgaha alınıp kesilir ve beze yapıldıktan sonra tepsilere dizilir. Dana döş etini (yağsız) zırh bıçağıyla kıyılır ve tencereye eklenir. Tencereye eklenen kıyma orta ateşte kavrulur. Kıyma hafif kavrulunca ince doğranmış soğan ve tereyağını eklenir. Soğanlar pembeleştiğinde tuz ve karabiber eklenip son kez karıştırılarak ocak kapatılır ve harç soğumaya bırakılır. Bezeler, hamur açma makinesinde bir miktar unla birlikte uzun ve ince olacak şekilde açılıp içerisine kıymalı harçtan eklenir ve hamur kapatılır (200 gramajdaki hamur için 200 gram kıymalı harç kullanılmalıdır). $450^{\circ} \mathrm{C}$ 'deki elektrikli fırında 4 dakika pişirilir. Pide piştikten sonra içine ya da üzerine isteğe göre bol ya da az tereyağı eklenir ve dilimlendikten sonra servis edilir." (KK6), bazısı "Tencere içerisine eklenen kıyma, suyunu salana dek orta ateşteki ocakta kavrulur. Suyunu salan kıymanın içerisine ince doğranmış soğan ve tereyağı eklenip kavurma işlemine devam edilir. 5 dakikalık bir kavurma işleminden sonra baharatlar eklenir ve karıştırılır. İç harç hazır olunca ocak kapatılır ve harç soğumaya bırakılır. Hamur için gerekli tüm malzemeler yoğurma kazanına eklenir ve kulak memesi kıvamında olana dek yoğrulur. Yoğrulan hamurun mayalanması için dinlendirilmeye bırakılır. Dinlenen hamur 200 gram olarak kesilip beze yapılır ve bu bezeler kasaya alınır. Daha sonra bu bezeler bir miktar un ve merdane ile birlikte uzun ve ince olacak şekilde açılır. Açılan hamurun içerisine 120-130 gram kadar harç eklenir ve üzeri kapatılır. 200-250 ${ }^{\circ} \mathrm{C}$ 'deki firındaki yan koltuklarda 5-8 dakika pişirilir. İsteğe bağlı olarak içerisine ya da üzerine tereyağı eklenip dilimlenir ve servis edilir." (KK7), bazısı "Hamur için gerekli malzemelerin hepsi hamur yoğurma makinesine eklenir ve yumuşak bir kıvam alana dek yoğrulması beklenir. Kıvama gelen hamur, 180-190 gram gelecek şekilde kesilip beze yapılır ve tepsilere dizilir. $50-60^{\circ} \mathrm{C}$ 'deki firını kenarına ya da altına konulan tepsiler konulur ve mayalama işlemi için 1.5-2 saat kadar beklenir. Hamur mayalanırken iç harç yapılır. Kıyma, tencereye eklenir ve kavrulması için firının yan koltuklarının olduğu yere bırakılır. 10 dakika sonra tencere çıkartılıp içerisine tereyağı eklenir ve içerisindeki kıyma ile birlikte harmanlanana dek karıştırılıp tekrar firına gönderilir. Fırının derecesi çok yüksek olmaması ve harcın ağır ağır pişmesi gerekiyor (hemen hemen 45 dakika kadar). Bu süreçte ara sıra tencerenin firından çıkartılıp karıştııılması gerekiyor. Kıyma suyunu saldıktan sonra ve bu suyu tekrar çektiğinde harcın kıvamını bulduğunu anlayabilirsiniz. Harç hazır olduğunda tencere fırından çıkartılır ve harcın soğuması için kenara alınır. Harç soğurken soğanlar soyulur ve doğranıp mutfak robotuna eklenir. Soğanlar, mutfak robotunda çok ince hale geleceğe kadar çekilir ve acılıklarının gitmesi için soğuk su dolu gastronoma eklenip 1 saat bekletilir. 1 saat sonra soğanlar el ile iyice sıkılıp suyundan arındırılır ve bir kaba alınır. 
Soğumuş kıymanın içerisine bu soğanlarla birlikte tuz ve karabiber de eklenip harmanladıktan sonra dinlendirilmeye bırakılır. Bezeler bir miktar unla birlikte hamur açma makinesinde açılır ve açılan hamur el ile uzatılır. Uzun ve ince hamurun içerisine 200 gram kadar iç harç eklenir ve hamur kapatılır. Hazır olan pidenin üzerine eritilmiş tereyağı sürülüp $350^{\circ} \mathrm{C}$ 'deki taş fırının ilk önce orta kısmında, daha sonra da yan koltuklarında 8-10 dakika kadar pişirilir. İsteğe bağlı olarak pidenin içerisine yumurta ya da kaşar peyniri eklenerek pidede çeşitlilik yapılabilmektedir." (KK8), bazısı "Kıyma tencereye konur ve orta ateş üzerinde karıştırılarak kavrulur. Kıyma suyunu salıp çektiği zaman ince doğranmış soğanlar da tencereye eklenir ve kavurma işlemine devam edilir. Hemen hemen bir 10-12 dakika kadar kavurma işlemine devam edildikten sonra içerisine tuz ve karabiber eklenip karıştırılır. Harç hazır olduğunda ocak kapatılır ve harcın soğuması beklenir. Harç soğurken pidenin hamuru hazırlanır. Hamur için gerekli tüm malzemeler hamur yoğurma makinesine eklenir ve yumuşak bir hamur olana dek makine çalıştırılır. Kıvama gelen hamur 30 dakika dinlendirilir. Dinlenen hamur kesilir ve kesilen hamur parçaları beze yapılır. Bezeler hamur kasalarına alınır ve 30 dakika dinlendirilir. Bezeler bir miktar un ve merdane ile birlikte ince ve uzunlamasına açılır. Açılmış hamurun içerisine kıymalı harç ve 1 çorba kaşı̆̆ı kadar tereyağı eklenir. İşlemi biten pidenin üzeri kapatılır ve fırında pişirilir. Bu işletmedeki firınlar doğalgazlı olduğu için derecesine ilişkin bir şey söylemem. Biz fırının 1sısını, tavına göre kendimiz ayarlıyoruz. Fırının tavına göre 5 dakika kadar kısa bir sürede pişirme işlemi gerçekleştiriliyor. Ancak pişirme işlemi için fırının yan koltukları tercih edilmelidir. Çünkü yan koltuklara konan pideler ağır ağır pişer ve daha lezzetli olur." (KK9), bazısı "Tencerenin içerisine kıyma eklenir ve orta ateşteki ocağın üzerinde devamlı karıştırılarak kavrulur. Kıyma suyunu salıp çektiğinde içerisine ayçiçek yağı ve ince doğranmış soğanlar eklenir. Yaklaşık 15 dakika kadar kavurma işlemine devam edilir. Kıvam alan harcın içerisine tuz ve karabiber eklendikten sonra son kez karıştırılır ve ocak kapatılır. Tencerenin içerisindeki harç bir gastronoma alınarak soğuması için kenara bırakılır. Hamur yoğurma makinesine tüm malzemeler eklenir ve makine çalıştırılır. Tüm malzemeler özleşene kadar yoğurma işlemine devam edilir. Hamur kıvamını bulduğunda 1 saat kadar mayalanması için kenarda bekletilir. 1 saat sonunda 170-180 gram olacak şekilde hamur kesilir ve beze haline getirilir. Bu bezeler de hamur kasalarının içerisine dizilir ve 30-45 dakika kadar kenarda dinlendirilmeye bırakı1ır $\left(+4^{\circ} \mathrm{C}^{\prime}\right.$ deki bir soğuk hava deposunda 1 gün dinlendirilse daha iyi olur.) Dinlenen bezeler bir miktar unla birlikte hamur açma makinesinde açıldıktan sonra el yardımıyla uzun bir hale getirilir. İçerisine yeteri kadar iç harç ve tereyağı koyarak pide kapatı1ır. $350^{\circ} \mathrm{C}$ 'deki taş fırında 10 dakika pişirilir. Pide firından çıkartılınca yan tarafından kesilip içerisine tereyağı eklenir ve üzerine de tereyağı sürüldükten sonra dilimlenerek servise hazırlanır. Yumurtalı Ereğli pidesi siparişi geldiğinde ise pide firından çıkartıldıktan sonra kapatılmış yerinden açılır ve ortasına yumurta kırılır. Pide kenarlarına da tereyağı parçaları eklenip üzerine tereyağı sürülür ve pide kapatılır. Pide kapatıldığında içerisindeki buharıyla birlikte hafif pişeceğinden dolayı tekrar firına gönderilmez. Ancak yumurtanın çok pişmesi istenirse tekrar firına gönderilir. Yumurtalı Ereğli pidesi dilimlenmez, pide kenarlarından kırılıp yumurtasına batırılarak yenir. Bu nedenle dilimlenmeden sunum tabağına alınıp servis edilmelidir." (KK10), bazısı "Hamur için gerekli tüm malzemeler hamur 
yoğurma makinesine eklenir ve makine çalıştırılır. Hamur hafif nemli ve ele yapışmayan bir kıvam aldığında makine durdurulur. Makine kazanındaki hamur tezgaha dökülür ve 170 gram olacak şekilde kesilip beze haline getirilir. Bu bezeler tepsilere dizilir ve soğuk hava deposunda 1 gün dinlendirilir. Ancak elimizde hamurumuz yoksa tepsileri firının kenarına ya da alt tarafina koyup 30 dakikalık bir dinlendirme işlemi yapıyoruz. İç harcını yapmak için kıyma tencereye eklenir ve orta ateşteki ocakta suyunu salana dek kavrulur. Suyunu salan kıymanın tekrar bu suyu çekmesi beklenir. Suyunu çeken kıymanın içerisine ayçiçek yağı ve yemeklik doğranmış soğanlar eklenerek kavurma işlemine devam edilir. Soğanlar kaybolmaya başladığında ocak kapatılıp tuz, karabiber ve ince doğranmış maydanoz eklenir. Tüm malzemeler son kez karıştırılarak soğumaya bırakılır. Hamur açma makinesinde bir miktar unla birlikte bezeler açılır. Ancak açılan hamurların el yardımıyla biraz daha ince ve uzun olacak şekilde ayarlanması gerekiyor. İdeal ölçüsünü bulan hamurun içerisine yeterli miktarda soğumuş harçtan eklenir ve hamurun üzeri kapatılır. Hazır olan pideler $290-330^{\circ} \mathrm{C}$ 'deki firında 8-10 dakika kadar pişirilir. Ancak fırın derecesini müşteri isteğine göre ayarladığımız da oluyor. Örneğin, müşterimiz pideyi çok iyi kızarmış ve gevrek olmasını istiyorsa dereceyi yükseltiyoruz ya da pideyi yumuşak istiyorsa dereceyi düşürüyoruz. Pişen pideler fırından çıkartılıp dilimlenir ve sunum tabağına alınarak servis edilir.” (KK11) cevabını vermiştir.

Ereğli pidesi yapılırken istenilen renk, tat, lezzet ve aroma gibi özelliklerin sağlanabilmesi için nelere dikkat edilmesi gerekir?" sorusuna bazısı "İç harca erken eklenen karabiber, harcın içerisinde acı bir tadın olmasına neden olur. Karabiberin kendine has tadını almak ve istenmeyen bir acılığa sebebiyet vermemek için ocak kapatıldıktan sonra karabiber eklenmelidir." (KK1), bazısı "İç harcında kullanılacak soğanlar mutfak robotunda çekilmemelidir. Çünkü mutfak robotunda çekilen soğanlar ezildiği için bir lezzet kaybı yaşanmaktadır. Bu lezzet kaybının önüne geçilmesi için de soğanların bıçakla doğranması gerekmektedir. Kullanılacak kıyma çok yağlı ise kavurma esnasında kıymanın fazla yağı alınmalıdır. Kıymadaki fazla yağın alınmaması, harcın çamur gibi olmasına neden olur. Hamuru dinlendirmeden önce üzerine çok az un dökmek ve bu unu, hamurun içerisinde hafif kalacak biçimde yoğurmak, hamurun daha iyi kıvam almasını ve daha lezzetli olmasını sağlamaktadır. Hamuru açarken de, unla birlikte bir miktar kepek kullanmak pidenin daha iyi kızarmasını sağlamaktadır." (KK2), bazıs1 "Maydanozların harcın içerisinde rengini kaybetmemesi ve canlı durması için kavurma işlemi bitip ocak kapatıldıktan sonra maydanozların eklenmesi gerekmektedir. Ereğli pidesinin çok ince bir hamuru olduğu için hamuru çok ince açmak gerekmektedir (Makine ile açıldığında da el ya da merdane yardımıyla biraz daha inceltilmelidir). Ereğli pidesine asıl tadı veren tereyağı olduğu için muhakkak iyi bir tereyağı seçilmelidir." (KK3), bazısı "Pidede lezzet kaybının yaşanmaması için iç malzemesindeki kıymanın doğal ortamda büyümüş bir besin hayvanın kıyması olduğuna, kullanılacak tereyağın da organik olduğuna dikkat edilmelidir." (KK4), bazısı "Hamurun yumuşak bir kıvamda olmasına ve mayalama işlemi için gerekli sürenin tanınmasına dikkat edilmelidir." (KK5), bazısı "İç harcı kavrulması sırasında kıymanın, tencere dibine sarmasına izin verilmemeli ve devamlı karıştırılmalıdır. 
Pişen harcın da mutlaka 10 dakika kadar dinlendirilmesi gerekmektedir." (KK6), bazısı "Hamuru açarken merdaneden değil ellerden yarım alınmalıdır. Çünkü merdane ile açılan hamur daha sert ve kuru olmaktadır. Ancak el ile açıldığında daha yumuşak ve güzel bir hamur elde edilmektedir. Hatta pidenin kızarması bile daha güzel olmaktadır. Hamurun güzel olması için de kullanılacak unun iyi kaliteli ve birinci sınıf bir un olduğuna dikkat edilmelidir." (KK7), bazısı "Soğanlar mutfak robotunda çekildiyse muhakkak soğuk suda 1 saat bekletilmelidir. Bu işlem yapılmadan hazırlanan pideler yenildiğinde ağızda istenmeyen ve baskın olan bir soğan acısı tadı oluşacağından mutlaka bu kurala uyulmalıdır." (KK8), bazısı "Dana kaburga etinden çekilmiş bir kıyma ile yapılan Ereğli pidesi daha lezzetli olduğu için kıymanın, bu etten çekilmiş bir kıyma olmasına dikkat edilmelidir. Kıymayı kavururken eklenen tereyağı herhangi bir lezzet sağlamadığı için iç harca tereyağı eklenmemelidir. Tereyağı, pideyi pişirmeden önce ve sonra pidenin içerisine eklenmeli, servis ederken de çok az üzerine sürülerek servis edilmelidir. Müşteri, pidenin yumurtalı olmasını istediyse pidenin fırından çıkarılmasına yakın yumurtası eklenmeli ve tekrar firına gönderilmemelidir. Çünkü pidenin içerisine eklenen yumurta, zaten pide içerisindeki buharla birlikte pişmektedir. Yumurta eklenen bir pidenin özelliği, yumurtanın çok pişmemesidir. Taş firınlarındaki ısı eşit derecede olduğu için bu firınlardaki pişirme işleminde pek bir sorun yaşanmamaktadır. Ancak elektrikli firınlardaki 1sı eşit olmadığı için pidelerin alt kısımları, üzerindeki kısma kıyasla daha çabuk kızarmakta ve istenmeyen yanıklara yol açmaktadır. Bu nedenle, elektrikli firın kullanılacağı zaman alt derece $\left(250^{\circ} \mathrm{C}\right)$ ve üst derece $\left(650^{\circ} \mathrm{C}\right)$ farklı olarak ayarlanmalıdır." (KK10), bazısı "hamurdaki kıvamın daha iyi sağlanması için soğuk suyla yoğrulması gerekmektedir." (KK11), bazıları "Kıymanın kavurma işlemindeki sürenin ve kavurma sırasında kullanılacak ateşin çok iyi ayarlanması gerekmektedir. Ateş, tencerenin her tarafına eşit bir şekilde dağılmalı ve kıyma ağır ağır pişirilmelidir. Kıymaya gerekenden daha az sürede bir kavurma işlemi uygulanırsa harçta istenmeyen ekşimsi bir tat ve koku oluşur." (KK2, 8, 9, 11), bazıları "Pideyi pişirme işlemi için mümkün olduğunca taş firın tercih edilmelidir. Çünkü pideye lezzet veren unsurlardan biri pidenin, bu firındaki odun ateşi ile ağır ağır pişmesidir." (KK1, 2, 7, 8, 10), bazıları "Pidenin pişirileceği esnada firının sıcaklığına dikkat edilmelidir. Gereğinden fazla sıcaklıktaki firında pişirilen pideler haşlama olur (çiğ kalır) ve firında bekledikçe üzerinde yanıklar oluşur. Çok soğuk bir firında pişen pidelerse kurur. $\mathrm{Bu}$ nedenle pideleri pişirme işlemi için fırının tav olması (pişirme derecesinin orta derecede olması) ve ağır ağır pişmesi gerekmektedir." (KK3-9), bazıları "Bazı ustalar hamuru uzun bir süre dinlendirmemek için içerisine eklenen maya miktarının arttırıyor. Ancak hamurun içerisine eklenen maya çok az olmalıdır. Böylece maya, hamur içerisinde kendine yavaş yavaş gelip içindeki malzemelerle özleşir, pidenin daha iyi kızarmasını sağlar ve piştiğinde çıtır çıtır olur.” (KK2, 10), bazıları "Hamur ne kadar fazla dinlenirse o kadar lezzetli ve çıtır çıtır olacağı için hamurun çok iyi dinlendirilmesi gerekmektedir." (KK10, 11), bazıları "Pişirme işlemi için firının ortası yani ateşe yakın yer tercih edilirse pide haşlama olur ve çiğ kalır. Ancak fırının yan koltukları tercih edilirse pide ağır ağır pişerek daha gevrek ve lezzetli olur." (KK2-8, 10) cevabını vermiştir. 
“Ereğli pidesini diğer pide çeşitlerinden ayıran özellik nedir?” sorusuna bazısı "az yağlı bir pide olduğu için hafif olması ve soğusa da lezzetini kaybetmemesi” (KK1), bazısı "Ereğli pidesi, Samsun'a ait pidelerle benzerlik gösteren bir pidedir. Ancak bu pide hamurlarında süt kullanılması ve hamurun biraz daha cıvık hazırlanması (ele yapışan) Ereğli pidesini farklılaştırmaktadır.” (KK2), bazısı "alt-üst çevrilerek pişirilmesi ve piştikten sonra içerisine tereyă̆ olması" (KK4), bazısı "İç harcın hazırlanması sırasında farklı baharatlar kullanılabilmektedir. Kullanılan baharat çeşitliliği de Ereğli pidesini diğer pide çeşitlerden ayıran bir özelliktir.” (KK6), bazısı "Ereğli pidesi, diğer pide çeşitlerine kıyasla daha geç bayatlar ve yenildiğinde ya da kesildiğinde içerisindeki malzemeler dökülmediği için yemesi de ikram etmesi de daha kolaydır. Çok yağlı bir pide çeşidi olmadığı için çatal ve bıçağa gerek duyulmadan el ile yenilebilir. Paketlemede de kolaylık ve tasarruf sağlayan bir pidedir. Örneğin, bir kuşbaşılı pide üst üste konulduğunda hamur olur ama Ereğli pidesinde böyle bir sorun yaşanmaz. Ereğli pidesi, Bafra ve Terme pidesine göre biraz daha kısa ve yassıdır. Ancak malzemesi daha boldur." (KK7), bazıları "İç harcındaki malzemelerin kavrularak hazırlanması ve pide hamurunun kapatılması" (KK1-6, 8-11), bazıs1 “Zonguldak’taki etlerin daha lezzetli olması" (KK10) cevabını vermiştir.

“Ereğli pidesini nasıl servis edersiniz? Kendine özgü bir servis şekli var mı?” sorusuna katılımcıların çoğu kendine özgü bir servis şekli olmadığını (KK1, 5-11), bazıları "yanında salata" (KK7, 9, 11), bazıları "yanında tarator, haydari ve ezme gibi meze çeşitleri" (KK4, 10, 11), bazıları "ahşap sunum tabaklarda dilimlenmiş bir şekilde" (KK2, 9), bazıları "iç harcında kullanılan kıymayı en iyi tamamlayan yan ürün ayran olduğu için yanında Susurluk ya da yayık ayranı” (KK3, 4, 7, 8, 10), bazısı "yanında közlenmiş biber" (KK6), bazıları "pişen pidenin içerisine tereyağı ekleme ve üzerine de tereyağı sürme" (KK7, 8, 10, 11) cevabını vermiştir.

“Ereğli pidesi muhafaza edilmeye uygun mudur? Nasıl muhafaza edilmelidir?” sorusuna bazısı "Ereğli pidesini tamamen soğuttuktan sonra ister dilimleyerek ister dilimlemeden dondurucuda 2 aya kadar saklayabilirsiniz. Örneğin, biz işletme olarak Rusya'dan da Ereğli pidesi siparişi alıyoruz. Pideleri dilimleyip işletmemize özgü kağıtlara sardıktan sonra difrizde dondurarak Rusya'ya gönderim sağlıyoruz ve herhangi bir sorunla karşılaşmıyoruz." (KK1), bazıları "Soğumuş Ereğli pideleri buzdolabında $\left(+4^{\circ} \mathrm{C}\right)$ 2-3 günü aşmayacağı sürece bekletilebilir." (KK1, 5, 8-11), bazısı "İç harcındaki malzemeler kavrularak hazırlandığı için muhafaza edilmeye daha uygun bir pide çeşididir. Ancak buzdolabında da difrizde de bekletseniz tadında bir lezzet kaybı olacaktır." (KK2), bazısı "Pişmiş pideyi buzdolabında ya da dondurucuda muhafaza ederseniz tadında değişmeler olacağı için muhafaza edilmeye uygun değildir. Ancak pidenin pişmemiş halini dondurucuda uzun süre, buzdolabında da $\left(+4^{\circ} \mathrm{C}\right)$ 2-3 güne kadar muhafaza edebilirsiniz. Dikkat edilmesi gereken nokta, dondurucudan çıkartılan pidelerin hemen pişirilmemesi gerektiğidir. 10 dakikalık bir çözdürme işlemi uygulandıktan sonra pideleri pişirebilirsiniz." (KK3), bazıları "İç harcı buzdolabında, hamuru da oda sıcaklığında 6 saati 
geçmeyeceği sürece bekletilebilir. Ancak pidenin pişmiş ya da pişmemiş hali buzdolabında da dondurucuda da muhafaza edilemez. Çünkü bekledikçe lezzet kaybı olur.” (KK4, 6), bazıları "dondurucuda yaklaşık 2-3 ay muhafaza edilmeye uygundur." (KK5, 8-10), bazısı "Diğer pidelere göre muhafaza edilebilirliği daha iyidir. Dondurucudan (6-8 aya kadar bekler) ya da buzdolabından (en fazla 3-4 gün bekletilebilir) çıkartıp mikrodalga ya da tavada 1sıttığınızda tadında bir değişiklik olmaz, aynı lezzetini korur.” (KK7) cevabını vermiştir.

"Ereğli pidesinin ne zamandan beridir yapıldığı hakkında bilginiz var mı?" sorusuna bazısı "14 yaşımdan (1994) beri bu pidenin varlığını biliyorum." (KK2), bazısı "74 yaşındaki dedem küçüklüğünden beri bu pidenin var olduğunu söylüyor." (KK3), bazıları "60 yıldan beri var olduğunu biliyorum ama daha eski de olabilir." (KK4, 5), bazısı "Benim çıraklık zamanımdan (1983) beri vardı." (KK9), bazısı "Çok eskiye dayalı, hatta babadan oğula ve dededen toruna geçme olayı var." (KK10), bazısı "Bir yazıda 78 yıllık bir pide olduğunu okumuştum" (KK11) cevabını vermiştir.

"Ereğli pidesinin sizin yörenizde yöresel başka adları var mı? sorusuna bazısı "Karadeniz pidesi” (KK5), bazısı "İlk yapıldığı zamanlarda kavrulmuş kıymalı olarak anılmış ama daha sonra Karadeniz Ereğli'de yapıldığı için bu ilçemizin adını almış ve öyle anılmaya başlamış." (KK7), bazısı "kapalı pide" (KK11) cevabını vermiştir. "Ereğli pidesinin bir hikayesi, şiiri veya manisi var mı?" sorusuna katılımcıların tamamı bilmediklerini belirtmişlerdir. Ancak bazısı, bir hikayeye sahip olduğunu duyduğunu ancak hatırlamadığını ifade etmiştir (KK5).

"Ereğli pidesi gibi yörenizde yapılan başka ekmek, börek, çörek var mı? Bildiklerinizin özelliklerini-yapılışını anlatabilir misiniz?” sorusuna bazısı "devrek ekmeği” (KK1), bazıları "bazlama” (KK4, 5, 7), bazıları "mancarlı ekmek" (KK5, 8), bazıs1 “tandır ekmeği” (KK6), bazıs1 “cevizli ekmek" (KK4) cevabını vermiştir. "Bildiklerinizin özelliklerini-yapılışını anlatabilir misiniz?” sorusuna ise bazısı "Bazlamayı genelde köylerdeki kadınlarımız yaptığı için yapılışı ya da özelliğini bilmiyorum. Cevizli ekmek ise normal ekmek hamuru gibi yapılıyor ama kullanılacak unun baklavalık un olması gerekiyor. Yoğrulup dinlemiş hamur, büyük yuvarlak şeklinde açılarak içine dövülmüş ceviz konuluyor ve dürüm halinde sarılarak burma şekli veriliyor. Daha sonra firında pişirilerek tüketiliyor.” (KK4), bazısı "Mancarlı ekmek, ekmek hamurunun altına ve üzerine mancarların (karalahana) dizilmesi ile yapılan bir ekmek çeşididir. Yıkanmış mancarlar tepsiye dizildikten sonra üzerine normal ekmek hamuru dökülüyor ve bu hamurun üzerine tekrar yıkanmış mancar yaprakları dizilerek firında pişiriliyor. Özelliği de hamurunun biraz daha tatlı ve yumuşak olması ile hamurun altına ve üzerine mancar dizilerek pişirilmesidir. Bazlama da genellikle köylerde yapılan bir köy ekmeğidir. Un, su, tuz ve maya ile yumuşak bir hamur yoğruluyor. Daha sonra beze yapılarak mayalanması için bekletiliyor. Daha sonra da kuzine üzerine koyulan tavada (yağ eklenmeden) pişiriliyor. Bu ekmeğin özelliği de kuzine üzerinde pişirilerek yapılıyor olmasıdır. Çünkü kuzine, daha farklı bir lezzet katıyor." (KK5), bazısı "Tandır ekmeği, pide hamurundan yapılan ve balon gibi kabaran bir ekmek çeşididir. Pide hamuru yoğrulduktan sonra tezgaha alınıp kesiliyor ve bezelere ayrılıp 1 saat mayalanması için dinlendiriliyor. Dinlenen 
hamur ince ve yuvarlak olacak şekilde açılıp üzerine yoğurt sürülerek $450^{\circ} \mathrm{C}$ firında 5 dakika pişiriliyor. Fırından çıktığında da nar gibi kızarmış ve kabarmış bir ekmek oluyor. Zaten puf gibi kabarması gerekiyor. Özelliği de üzerine yoğurt sürülmesi ve bir balon gibi kabarmasıdır.” (KK6), bazıs1 "Bazlama, genelde köylerde yapıllyor. Ereğli pidesinin hamuru gibi bir hamur yoğruluyor ve bu hamur yuvarlak olacak biçimde açılıyor. Hazırlanan hamurlar da odun ateşi üzerindeki toprak sacların üzerinde pişiriliyor." (KK7), bazısı "Mancarlı ekmek için bir ekmek hamuru hazırlanıyor ama bu hamurun malzemelerini bilmiyorum. Ekmeğin pişeceği tepsinin altına yıkanmış mancar yaprakları serilip üzerine ekmek hamuru dökülüyor ve bu hamurun üzerine de tekrar mancar yaprakları diziliyor. Daha sonra firın yakılıyor ve fırının soğuması bekleniyor. Fırın soğuduğunda ekmek tepsisinin üzerine kapak kapatılıp bu fırının içerisindeki yan koltuklarda 1-2 saat pişmesi için bırakılıyor. Bu ekmeğin özelliği buz gibi bir soğuk firında pişmesidir.” (KK8) cevabını vermiştir.

\section{Tartışma}

Türk mutfak kültüründe hamur işlerinin ayrı bir öneme sahip olduğu aşikârdır. Türkiye'de sıklıkla tüketilen hamur işleri arasında pideler ön plana çıkmaktadır. Hemen hemen her bölge mutfağında yer alan pidelerin özellikle Karadeniz bölgesinde yoğunlaştığı görülmektedir. Kullanılacak etlerin doğal besi hayvanı olmasına ya da özel otlarla beslenmesine dikkat edilmesi, hamuru için doğal kaynak sularının tercih edilmesi, hamurların mayalı (ekşi, yaş) ya da mayasız yapılması, pişirme işlemi için özel firın ve farklı odunların seçilmesi, iç malzemeleri için yöre mutfağına özgü sebze (ot) ya da peynirlerin kullanılması gibi etkenler ile çeşitli pideler hazırlanmaktadır. Pidelerin çeşitlilik göstermesi, her yörenin kendi mutfağına göre şekillenmesinden kaynaklanmaktadır.

Zonguldak'ın meşhur Ereğli pidesi de, ilin tüm ilçelerinde hâkimiyet kuran ve Ereğli'deki lokantaların hemen hemen hepsinde sıklıkla yapılan özel bir lezzettir. Tarihçesi ile ilgili net bir bilgi olmamakla beraber katılımcılardan edinilen bilgiler doğrultusunda yapımının 1940'lı yıllara dayandığı tespit edilmiştir. Üretimi Karadeniz Ereğli’ de başladığı için adını da bu ilçeden alan yöresel lezzetin kim tarafından bulunduğu ile ilgili kesin bir bilgi yer almamaktadır. Görüşme sağlanan kişiler tarafindan Ereğli pidesinin Karadeniz pidesi (KK5), kavrulmuş kıymalı (KK7) ya da kapalı pide (KK11) olarak anıldığı da bildirilmiştir. Bazı kaynaklarda ve internet sitelerinde de Karadeniz Bölgesi'nde yaygın yapılan Karadeniz pidesi ya da Karadeniz içli pidesi isimli bir pide görülmektedir (Vikipedi Özgür Ansiklopedisi, 2021). İnternet paylaşımlarına göre tüm bölge pidelerine Karadeniz pidesi denildiği düşünülmektedir. Civelek (2006: 194)'in verdiği tarife göre ise; Ereğli pidesinden farklı olarak Karadeniz pidesinin iç harcında soğan bulunmamaktadır. Karaosmanoğlu, Üstün ve Karaosmanoğlu'nun (2011) yaptığı çalışmada, kıymalı, peynirli, kaşarlı, kavurmalı, sucuklu, kuşbaşı etli ve karışık çeşit olarak hazırlanan Giresun pidesine de Karadeniz pidesi denildiği görülmektedir. Giresun (Karadeniz) pidesi, yapım malzemeleri ve hazırlama aşamaları ile Ereğli pidesine benzerlik gösterse de, pide eninin daha geniş olması ve üzerine yumurta sarılı bir bulamaç sürülmesi ile Ereğli 
pidesinden farkl11ık göstermektedir.

Literatürde orijinal Ereğli pidesinin malzemeleri ve yapımı ile net bir bilgi yer almamasına karşın internet kaynaklarındaki yazılı bilgilere göre; iç malzemelerinde domates, soğan, sivri biber, kıyma, karabiber, hamur malzemelerinde ise tam buğday unu, su, kuru maya, şeker ve tuz yer aldığ1 görülmektedir. Ayrıca iç malzemenin pişirilmeden hazırlandığı ve pideye açık form verilerek pişirildiği belirtilmektedir. Ancak katılımcılar tarafından sağlanan bilgiler doğrultusunda Ereğli pidesinin malzemeleri için un, su, tuz, yaş maya, şeker, kıyma, soğan, tereyağı, karabiber ve isteğe göre maydanoz kullanıldığ Kullanılan malzemeler arasında tereyağı yerine ayçiçek yağı ya da zeytinyağı kullanılabildiği, baharatların da çeşitlendirilebildiği edinilen bilgiler arasındadır. Pidenin iç malzemesinin taş firında kavrulması, pişirme işlemi için taş firının tercih edilmesi ve kullanılacak kıymanın kaburga etinden tercih edilmesine özen gösterilmesi pidenin lezzetini etkilerken, kaşar peynirli, soğansız ya da yumurtalı olarak hazırlanması da pidenin çeşitlenmesine katkı sağladığı ifade edilmiştir. Baba mesleğini sürdüren meşhur pideci Hasan Kuru da, Ereğli pidesini özel kılan unsurların "hamurun en az 1 saat dinlenmesi, harcın ve pidenin odun ateşinde ağır ağır pişirilmesi, pişirilen harcın soğumaya bırakılması ve yağının alınması, hamurunun elle açılması, iç malzemenin bol konulması, hamurunun kapalı formda olması, pişmeye yakın çıkartılıp içerisine ve üzerine tereyağı eklenmesi, gevrekliğini uzun süre koruması" olduğunu belirtmiştir (Sertel, 2018). Ereğli pidesi yapımı ile ilgili fotoğraflar Şekil 2, Şekil 3.1. ve Şekil 3.2.'de verilmiştir.

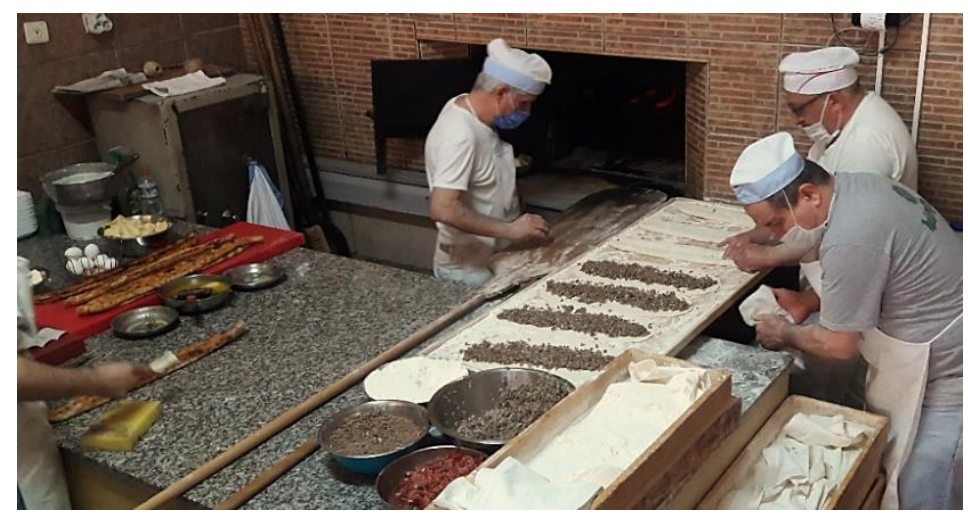

Şekil 2. Bir Lokantanın Fırın Bölümünde Hazırlanan Ereğli Pideleri (Fotoğraf: Elif KURT)
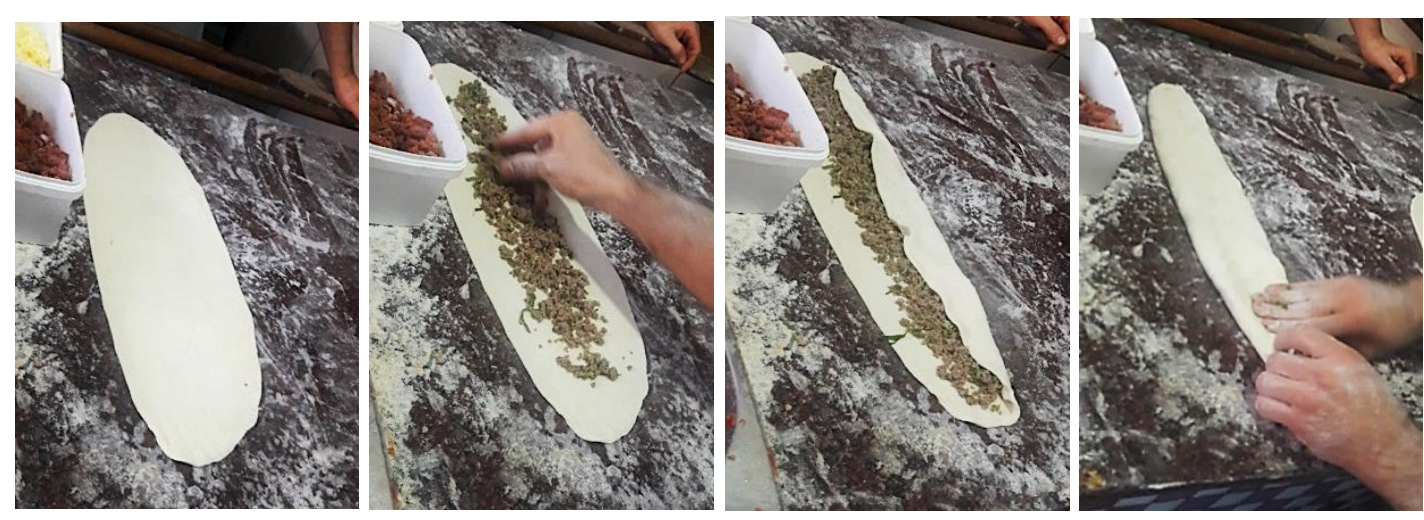

Şekil 3.1. Ereğli Pidesinin Yapım Aşamaları (Fotoğraf: Elif KURT) 

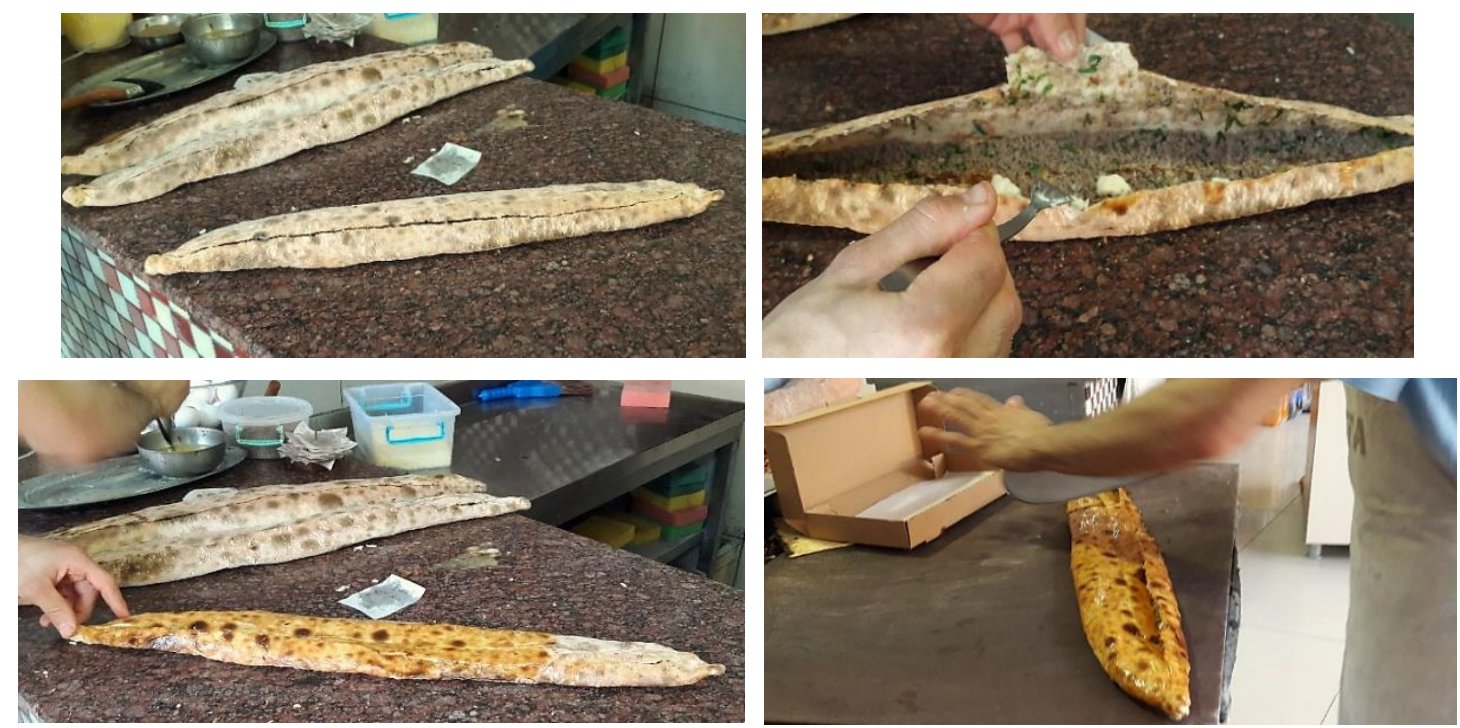

Şekil 3.2. Odun Ateşinde Pişirilen Ereğli Pidesine Tereyağı Eklenmesi Ve Dilimlenmesi (Fotoğraf: Elif KURT)

Özdemir'e (2020: 99-100) göre; Ordu-Ünye, Samsun-Bafra ve Terme pideleri hamur kalınlığ1, şekli (daha küçük ve geniş kayık modeli) ve bazı restoranlarda yuvarlak şekilde servis edilmesi ile Espiye pidesinden ayrılmaktadır. Çalışmada görüşme sağlanan kişiler ise Samsun'a özgü pidelerin daha uzun açılması, pide hamuruna süt eklenmesi ve hamurun ele yapışan kıvamda hazırlanması ile Ereğli pidesinden ayrıldığını beyan etmiştir (KK5, 7). Bafra pidesine ilişkin yapılan bir çalışmada ise (Canbolat, Keleş ve Akbaş, 2016: 80-81); Bafra pidesinin hamuruna şeker eklenmemesi, kıymanın kavrulduktan sonra tüm yağının alınması, soğanların kavrulmadan iç harca eklenmesi, pidenin daha uzun boyutta olması ve kullanılan tereyağının Bafra yöresine özgü tercih edilmesi gibi özellikler ile Ereğli pidesinden farklılaştığı görülmektedir. Espiye pidesinin Ereğli pidesinden ayrılan özelliği ise; yanında turşu ya da turşu kavurması servis edilmesi ve uzunluğunun bir metre üzerinde olmasıdır (Özdemir, 2020; 100).

Seçim (2018), Konya etliekmeğin genel özelliklerine ilişkin bir çalışma gerçekleştirmiştir. Yapılan çalışmada, etliekmek için farklı dilimleme şekilleri (merdiven, çatalağzı, kuşyuvası) kullanılabildiği, ekmeğin uzun, geniş ve açık pide formunda hazırlandığı, fırında kullanılacak odunların meşe ve çırasız çam olmasına dikkat edildiği, iç harcına kıyma (koyun ya da kuzu) dışında domates, biber ve kavram yağı eklendiği, hamuru için beyaz-esmer ya da 4 çeşit unun tercih edildiği ve firın içerisindeki sille taşında pişirilmesi gerektiği bildirilmiştir. Üretim metodu olarak Ereğli pidesine benzerlik gösteren etliekmeğin, görünüm, servis şekli ve pişirme yöntemleri açısından farklılaştığı görülmektedir. Türkiye Kültür Portalı'ndan edinilen bilgiye göre ise; Ereğli pidesinin iç harcında kullanılan malzemeler ile Daday etli ekmeğine daha çok benzerlik gösterdiğini söylemek mümkündür. Ereğli pidesine benzerlik gösteren bir diğer pide ise; Bozdoğan'a özgü yuvarlak kıymalı pide olarak da bilinen yuvarlaktır. Ancak Bozdoğan pidelerine özgü yapılan bir çalışmada (Baysal, Kurnaz ve İşlek, 2018: 2509-2511), yuvarlağın iç harcına domates eklendiği, hamurunun biraz daha kalın açıldığı, hamur 
malzemeleri için özel Madran memba suyu, söke unu, zeytinyağ 1 ve süt kullanıldığı, pideye yuvarlak şekli verildiği ve yanında turunç ile servis edildiği belirtilmiştir.

Karadeniz bölgesine ait birçok pidenin coğrafi işareti alması pidenin zengin ve çeşitli yapıldığının kanıtıdır, ancak aralarında ne gibi farkların olduğu konusunda daha kapsamlı bir çalışmanın yapılması gerektiği düşünülmektedir. Ayrıca Zonguldak iline has diğer yöresel ürünlerin de literatüre kazandırılması için bu alana yönelik çalışmaların yürütülmesine ve arttırılmasına teşvik edilmesi gerekmektedir.

\section{Sonuç ve Öneriler}

Ereğli pidesinin tanıtılması amacıyla gerçekleştirilen çalışmada, kaynak özelliklere sahip kişiler ile görüşülerek Ereğli pidesine ilişkin bilgiler toplanmıştır. Edinilen bilgiler doğrultusunda, Ereğli pidesinin yapımında kullanılan malzeme ölçüsü ve araç gereçler, hazırlama, pişirme ve muhafaza yöntemleri, servis şekli, diğer pidelerden ayrılarak kendine has sergilediği özellikleri ve dikkat edilmesi gereken noktalar elde verilerin işlenmesi sonrası sunulmuştur. Araştırma sonucuna göre; "Ereğli pidesinin Zonguldak'a has bir ürün olduğu ve sık sık tüketildiği, Ereğli pidesinin salata, meze çeşitleri, ayran ve içerisine tereyağının eklenmesi ile servis edildiği, Ereğli pidesinin hamurunda aslında maya kullanılmadığı ama işleyişi hızlandırmak için az miktarda eklendiği, Ereğli pidesinin kendine has lezzeti için pişirme işleminin taş fırınlarda yapılması ve gevrekliğinin sağlanması için de taş fırının içerisindeki yan koltuklarda ağır ağır pişirilmesi gerektiği, Ereğli pidesinin tadında değişmeler yaşanabileceği için muhafaza edilmeye çok uygun bir ürün olmadığı” bilgileri edinilmiştir. Edinilen bilgiler arasında, işleyişi hızlandırmak için elektrikli fırın, hamur yoğurma ve açma makinelerinden yararlanıldığı da yer almaktadır. Ancak yararlanılan yöntemlerin yetişmekte olan ustaların el maharetlerinin gelişememesine, geleneksel lezzet ve yöntemlerin sürdürülememesine neden olacağı düşünülmektedir. Kat1lımcılar, Ereğli pidesi gibi Zonguldak'a has olan ama çok bilinmeyen ekmek çeşitlerinin (Devrek ekmeği, mancarlı ekmek, cevizli ekmek, tandır ekmeği) olduğunu da aktarmıştır.

Ereğli pidesinin kaybolmaması ve gelecek kuşaklara aktarılması için standart tarifinin oluşturulması ve coğrafi işaret ile tescillendirilerek koruma altına alınması önem arz etmektedir. Lise ve üniversite bünyelerinde yer alan yiyecek içecek hizmetleri, aşç1lık ve gastronomi bölümlerinde bölge mutfaklarında öne çıkan yöresel lezzetlere ilişkin daha kapsamlı teorik derslere yer verilmesi ve konuya ilişkin yarışma, söyleşi, workshop vb. etkinliklerin düzenlenmesi ile yöresel lezzetlerimizin bilinirliği arttırılmalıdır. "Derepazarı Pide ve Turizm Festivali, Yenipazar Geleneksel Pide Festivali, Kadınhanı Tahinli Pide Festivali, Vakfıkebir Ekmek ve Kültür Festivali...” gibi ülke çapında yöresel fuar organizasyonlarının düzenlenmesi ve yöresel lezzetlerin bu fuarlarda sergilenerek tanıtımlarının yapılması Ereğli pidesi ve Zonguldak'a has diğer lezzetlerin bilinirlikleri arttırılmasına katkı sağlayacaktır. Ayrıca, yazılı ve görsel materyaller ile küresel ölçekte de tanıtımının yapılıp yaygınlaştırılması gastronomi turizmine olumlu bir katkı sağlarken bölgenin kültürel yönleri ile 
tanınmasına da imkân verecektir.

Yazar Katkısı: Bu çalışmanın gerçekleştirilmesinde iki yazar da eşit oranda katkı sağlamıştır.

Çıkar Beyanı: Bu çalışmada yazarlar arasında herhangi bir çıkar çatışması bulunmamaktadır.

\section{Kaynaklar}

Akbıyık, D. (2021). Zonguldak mutfak kültürü. Erişim adresi: http://www.gundem67.com/gundemozel/zonguldak-mutfak-kulturu-h90597.html

Aksoy, M. ve Üner, E. H. (2016). Rafine mutfağın doğuşu ve rafine mutfağı şekillendiren yenilikçi mutfak akımlarının yiyecek içecek işletmelerine etkileri. Gazi Üniversitesi Sosyal Bilimler Dergisi, 3(6), 1-17.

Arıkan, A. D. (2019). Türk mutfağında geleneksel ekmek pişirme yöntem, araç ve gereçlerinin yaşatılması: Pileki örneği. Karadeniz Uluslararası Bilimsel Dergi, (41), 52-61. https://doi.org.10.17498/kdeniz.480663

Badem, A. (2021). Ekmek ve unlu mamuller. Edi: Geçgin, E. ve Baltac1, M. Temel Mutfak Teknikleri ve Yönetimi içinde. Ankara: Detay Yayınc1lı. ISBN: 978-605-254-394-8.

Badem, A. ve Akturfan, M. (2020). Yöresel bir çorba: Arabaşı (Arap aşı, Ara aşı). Küçüktı̆̆lı, M. S., Seçim, Y., Adabalı, M. M. ve Yılmaz, M. (Ed.), Anadolu Mutfak Kültüründen Esintiler (s. 48) içinde. Konya: Konya Büyükşehir Belediyesi Kültür Yayınları.

Batı Karadeniz Kalkınma Ajansı (BAKKA). (2016). Zonguldak için yeni lezzetler. İstanbul: Mavi Ofset. $8-25$

Baysal, K., Kurnaz, A. ve İşlek, E. (2018). Yöresel yemeklerin gastronomik ürün olarak kullanılması: bozdoğan pideleri örneği. Journal of Social and Humanities Sciences Research, 5 (26), 25052514.

Berard, L. ve Marchenay, P. (2006), "Local products and geographical indications: Taking account of local knowlodge and biodiversity", International Social Science Journal, 187, 1009-1016.

Beşirli, H. (2010). Yemek, kültür ve kimlik. Milli Folklor, 22(87), 159-169.

Canbolat, E., Keleş, Y. ve Akbaş, Y. Z. (2016). Gastronomi turizmi kapsamında samsun mutfağına özgü turistik bir ürün: Bafra pidesi. Journal of Tourism and Gastronomy Studies (4), 4, 75-87. https://doi.org.10.21325/jotags.2016.49

Civelek, H. (2006). Karadeniz'de lezzet yolculuğu. İstanbul: İnkılap Kitabevi. ISBN: 975-10-2419-6.

Cömert, M. ve Özata, E. (2016). Tüketicilerin yöresel restoranları tercih etme nedenleri ve Karadeniz mutfağı örneği. Journal of International Social Research, 9(42).

Çelik, D. Y. (2010). Mengen'de özel gün yemekleri. Milli Folklor Dergisi, 86, 127-139.

Çetinkaya, N. (2020). Orta Asya'dan Selçuklu'ya Anadolu mutfă̆ı. Edi: Akbaba, A. ve Çetinkaya, N. Gastronomi ve Yiyecek Tarihi içinde. Ankara: Detay Yayıncılık. ISBN: 978-605-2323-67-0.

Çetinkaya, N., Şimşek, A. ve Yıldız, S. (2019). Anadolu'nun mirası ekmeklerin dini açıdan önemi. Edi: Harman, S., Kaya, O. ve Yurtseven, R. Mutfak Mirası ve Yadigar Ürünler içinde. Ankara: Detay Yayınc1lik. ISBN: 978-605-254-099-2.

Emeksizoğlu, B. (2017). Anadolu'nun lezzetli ekmekleri. Türk Tarım Dergisi, (235), 24.

Güvenç, B. (1999). İnsan ve kültür. Ankara: Remzi Kitabevi.

Halıcı, N. (1999), Siniden tepsiye klasik türk mutfağı. İstanbul: Numune Matbaacılık.

Işık, N., Kılıçarslan, A., Güldemir, O., Derin, D. Ö., ve Barı, N. (2017). Ilgın mutfak kültürü ve yemekleri. Selçuk Üniversitesi Sosyal Bilimler Enstitüsü Dergisi, (38), 86-94. 
Işın, P.M. (2021). Yemeğin kültürel tarihi. İstanbul: Yapı kredi Yayıncılık.

Işkın, M. ve Sarışık, M. (2019). Karadeniz Bölgesi mutfağı. Sarışık, M. ve Özbay, G. (Ed.), Ulusal Gastronomi ve Türk Mutfağı içinde. Ankara: Detay Yayıncılık.

Karaosmanoğlu, H., Üstün, Ş.N. ve Karaosmanoğlu, A. (2011). Doğu Karadeniz Bölgesindeki gida turizmi ve geleneksel gidalar. Akyurt, H. ve Yağcı, K. (Yay. haz.) Uluslararası Doğu Karadeniz Turizm Sempozyumu, 7-8-9 Ekim 2010, Giresun, Bildiriler Kitabı içinde (s.181). ISBN: 978-975-01408-7-7.

Kozak, M. (2018). Bilimsel araştırma: Tasarım, yazım ve yayım teknikleri. İstanbul: Detay Yayıncılık.

Nöraşin, S. (2014). Yöresel mutfak kültürü. Eren, S. (Ed.), Zonguldak Yemekleri içinde. Ankara: Ankara Ofset.

Özdemir, M. (2020). Coğrafi işaretler ve türk mutfak kültüründe bir imge: Espiye pidesi. Avrasya Uluslararası Araştırmalar Dergisi, 8 (25), 92-104. https://doi.org.10.33692/avrasyad.836094

Sabbağ, Ç. ve Boğan, E. (2019). Türk mutfağını gelişim sürecine genel bakış. Sarışık, M. ve Özbay, G. (Ed.), Ulusal Gastronomi ve Türk Mutfăğ içinde. Ankara: Detay Yayıncılık.

Saunders, M., Philip L., and A., Thornhill. (2012). Research methods for business students. New Jersey: Pearson Education Limited.

Seçim, Y. (2018). Yöresel bir ürün olan Konya etliekmeği ve genel özellikleri hakkında nitel bir çalışma. Journal of Tourism and Gastronomy Studies, 6(4), 197-209. https://doi.org.10.21325/jotags.2018.304

Sertel, E. (2018). Ezgi Sertel ile lezzetin haritası Zonguldak-Ereğli (Video). Erişim adresi: https://www.youtube.com/watch?v=vdlzbV5XgjM\&t=471s

Sürücüoğlu, M. S. ve Özçelik, A. Ö. (2007). Türk mutfak ve beslenme kültürünün tarihsel gelişimi. ICANAS, Uluslararası Asya ve Kuzey Afrika Çalışmaları Kongresi, 10-15.

Şengül, S. ve Türkay, O. (2015). Doğu Karadeniz mutfak kültürünün sürdürülebilirliği sorunlar ve çözüm önerileri. Akdu, U. ve Çalık, İ. (Ed.), Doğu Karadeniz Bölgesi Sürdürülebilir Turizm Kongresi Bildiri Kitabı içinde. Trabzon: Harman Yayıncılık. 599-606.

Şengül, S. ve Türkay, O. (2016). Akdeniz mutfak kültürünün gastronomi turizmi bağlamında değerlendirilmesi. Journal of Tourism and Gastronomy Studies, 4(1), 91. https://doi.org.10.21325/jotags.2016.24

Tez, Z. (2021). Lezzetin tarihi. İstanbul: Hayy Kitap. ISBN: 978-605-4325-87-0.

Vikipedi Özgür Ansiklopedisi, (2021, 29 Nisan). Erişim adresi: https://tr.wikipedia.org/wiki/Karadeniz_pidesi

Yerasimos, M. (2019). 500 Ylllık Osmanlı Mutfă̆ı. İstanbul: Boyut Matbaacılık. 